\title{
Modeling the soil nutrient balance of integrated agriculture- aquaculture systems in the Mekong Delta, Vietnam
}

\author{
L. T. Phong • J. J. Stoorvogel • \\ M. E. F. van Mensvoort • H. M. J. Udo
}

Received: 2 August 2009/Accepted: 12 October 2010/Published online: 27 October 2010

(C) The Author(s) 2010. This article is published with open access at Springerlink.com

\begin{abstract}
This study quantifies soil nutrient balances of Integrated Agriculture-Aquaculture Systems in the Mekong Delta of Vietnam. Eleven farms were monitored to collect data on farm activities and nutrient inputs and outputs to compute these balances of the rice-based and high input fish system in O Mon district (R-HF); the rice-based and medium input fish system in Tam Binh district (R-MF); and the orchardbased and low input fish system in Cai Be district (O-LF). For the estimation, the Nutmon model has been adapted to the specific conditions in these integrated systems in Asia (Nutmon-Asia). New regression models of leaching and gaseous losses of nitrogen were applied to fields used for upland crops and paddy rice. Reference values were used for the assessment of nitrogen fixation in paddy soils, wet atmospheric deposition, and irrigation water. The results showed that farms in all three systems have
\end{abstract}

L. T. Phong

College of Agriculture and Applied Biology, Can Tho

University, 3/2 Street, Can Tho City, Vietnam

J. J. Stoorvogel $(\bowtie) \cdot$ M. E. F. van Mensvoort Land Dynamics Group, Wageningen University, P.O. Box

47, 6700 AA Wageningen, The Netherlands

e-mail: jetse.stoorvogel@wur.nl

H. M. J. Udo

Animal Production Systems Group, Wageningen University, P.O. Box 338, 6700 AH Wageningen,

The Netherlands nitrogen, phosphorus and potassium surpluses $\left(84 \mathrm{~kg} \mathrm{~N}, 73 \mathrm{~kg} \mathrm{P}\right.$, and $69 \mathrm{~kg} \mathrm{~K} \mathrm{ha}^{-1}$ year $^{-1}$ ). The O-LF system had the smallest nitrogen surplus while the smallest surplus of phosphorus and potassium was seen in the R-HF system. High surpluses of phosphorus and potassium were found in vegetable fields, whereas a negative potassium balance was found in the rice fields of all three systems. The positive farm nutrient balances indicate that it is likely that soil fertility will be maintained although there is a risk for environmental contamination.

Keywords Integrated agriculture-aquaculture Mekong Delta $\cdot$ Nutmon $\cdot$ Nutrient balance $\cdot$ Fish ponds

\section{Introduction}

In the Mekong Delta of Vietnam (MD) the development of integrated agriculture-aquaculture (IAA) farms has been driven by food security, economic liberalization, market demands, and natural disasters (e.g., flooding). These IAA farms combine paddy rice, vegetable fields, orchards, livestock, and fish ponds. Recently, management on these farms intensified in terms of input use and production (Phong et al. 2008). Because of diversification and integration it is claimed that IAA systems use resources (e.g., land and soil nutrients) efficiently with minimal 
emissions (Gooley and Gavine 2003). Such claims, however, have rarely been supported by quantitative evidence.

Soil nutrient balances can be used as an indicator to determine nutrient use efficiency of farming systems (Van der Pol 1992; Stoorvogel 2007; Cobo et al. 2010). Different tools that quantify the nutrient balances have been discussed in the literature (Roy et al. 2003). This study uses Nutmon (Smaling and Fresco 1993) which has proven to be a powerful tool for assessing soil nutrient balances (Lynam et al. 1998). The concept of Nutmon is based on an analysis of nutrient inputs and outputs. Nutrient flows like fertilizers, feeds, and farm products are monitored and measured. Other flows like nitrogen fixation, leaching, and erosion are more difficult to measure and are estimated by means of regression models. Nutmon is originally developed for African farming systems (Stoorvogel and Smaling 1990; Smaling et al. 1993; Smaling and Fresco 1993; De Jager et al. 1998; Van den Bosch et al. 1998; Vlaming et al. 2001) where numerous studies have been carried out in Kenya (De Jager et al. 1998; Van den Bosch et al. 1998; Gachimbi et al. 2002; Muendo 2006), Ethiopia (Abegaz 2005), Uganda and Burkina Faso (Agwe et al. 2007). These studies in SubSaharan Africa reveal, almost unequivocally, alarming nutrient depletion rates (Stoorvogel 2007). The nutrient balances can serve as indicators for the magnitude of losses of nutrients and help to identify the causes for such losses. Recently Nutmon has been applied in Asia including India (Surendran et al. 2005; Surendran and Murugappan, 2006), China, Vietnam (Vlaming et al. 2001; Howeler 2001; Lam et al. 2005; Khai et al. 2007; Dang 2005), and Thailand (Wijnhoud 2007). However, since the regression models in Nutmon have been developed for African conditions, studies outside Africa base their assessment on the flows that can be easily measured or monitored leaving out important, more difficult-to-measure nutrient flows like leaching, gaseous losses, and erosion. The resulting so-called partial balances are rather awkward to interpret as positive and neutral balances do not necessarily correspond to sustainable farming systems.

The question that remains is whether the methodology that was designed for the low external input African farming systems can be adapted for other agro-ecosystems and still yields a reasonable estimate of the full nutrient balance. Various difficulties can be encountered in applying Nutmon to South-East Asia or more specifically to IAA systems in the MD. The systems are, contrary to the African systems, intensive with high inputs, multiple cropping, and with high use of irrigation water. In addition, fish ponds are a common component of IAA systems in the MD. A pond can trap run-off water and its sediments can subsequently be used as an on-farm crop fertilizer and improve on-farm nutrient retention and utilization efficiencies (Muendo 2006). Those differences in farm management call for an adjustment of the estimation of some of the hard-to-quantify flows. This study aims to (1) adapt Nutmon to South-East Asia to quantify the nutrient balances in IAA farms in the MD, and (2) evaluate the sustainability of IAA farming systems in the MD with respect to soil nutrient balances.

\section{Materials and methods}

Study sites and farm selection

The MD covers approximately 3.9 million ha and is located between $104^{\circ} 26^{\prime}$ to $106^{\circ} 47^{\prime}$ eastern longitude and $8^{\circ} 33^{\prime}$ and $11^{\circ} 02^{\prime}$ northern latitude. Except for some minor hilly areas, the MD is flat and low-lying with an average altitude of about 2 meters above sea level (Hoa 2003). The MD has a tropical monsoon climate with an average annual temperature of $27.2^{\circ} \mathrm{C}$. There are two distinct seasons: (1) the rainy season with southwestern winds from May to November, and (2) the dry season with northeastern winds from December to April. Average annual rainfall varies between 1,200 and $2,400 \mathrm{~mm}$ of which about $90 \%$ occurs in the wet season. With many natural streams and a dense network of man-made canals, the MD has complex hydraulics. Prolonged heavy rains, combined with water from the huge upstream catchments of the Mekong river, result in flooding (usually from August to November) of the delta with an average flooding depth of $0.8-1.5 \mathrm{~m}$ (Nga 2004). Acid sulphate soils occur widely throughout the MD, but prevail in the back swamps and make up a total of $45 \%$ of the MD (White 2002).

Eleven representative IAA farms were selected from a large rapid rural appraisal (Phong et al. 2008). The farms were located in three fresh water districts 
in the MD: (1) in $\mathrm{O}$ Mon district (R-HF) $\left(105^{\circ} 36^{\prime} \mathrm{E}\right.$; $\left.10^{\circ} 07^{\prime} \mathrm{N}\right)$ having a rice based system with high input (mainly pelleted food) fish ponds, (2) in Tam Binh district $(\mathrm{R}-\mathrm{MF})\left(105^{\circ} 53^{\prime} \mathrm{E} ; 10^{\circ} 07^{\prime} \mathrm{N}\right)$ having a ricebased system with medium input (farm residues, manure, and some pelleted food) fish ponds, and (3) in Cai Be district (O-LF) $\left(106^{\circ} 00^{\prime} \mathrm{E} ; 10^{\circ} 24^{\prime} \mathrm{N}\right)$ having an orchard-based system with low input (farm residues and manure) fish ponds.

\section{Farm monitoring}

Household characteristics, size of agricultural fields and fish ponds, farm activities, nutrient inputs and outputs of the farm components, internal resource use, herd and flock growth, livestock management, livestock manure, household consumption, and household waste were recorded from September 2002 to September 2004 in a dynamic survey. During the survey, farms were visited on a monthly basis to monitor farm inputs and farm outputs. During the entire survey farmers kept log books of all farm operations. Farmers registered the quantities of inputs and outputs using local units (e.g., bags). On separate occasions conversion factors between local units and weights were determined. Dry matter contents and nitrogen $(\mathrm{N})$, phosphorus $(\mathrm{P})$ and potassium $(\mathrm{K})$ concentrations of farm products and by-products were based on FAO (1972) and FNRI (1990). The nutrient concentrations in faeces of pigs, poultry, goats, and rabbits were based on studies by Nhan (2008), Yem et al. (2001) and Can (1982) whereas the nutrient concentration in weeds and grass was based on Dung (1996). The nutrient values of inorganic fertilizers and purchased feed concentrates were recorded from their trade marks.

Soil samples were taken at the beginning, the middle and the end of monitored period to a depth of $20 \mathrm{~cm}$ in rice fields, vegetable fields and fish ponds, and to a depth of $50 \mathrm{~cm}$ in homestead and orchard beds. Five soil samples in each land use system on each farm were collected and analyzed for organic matter through the measurement of loss on ignition, nitrogen using the Kjeldahl methodology, available phosphorus using Bray-2, and exchangeable potassium with an $\mathrm{BaCl}_{2} 0.1 \mathrm{~N}$ solution. Details on the methods are described in DHCT (2006). Data of the 5 different replicates and three sampling dates were averaged per land use system to estimate soil nutrients stocks of the cropping systems in the three systems.

\section{Nutmon}

Nutmon uses a conceptual model that distinguishes various compartments on the farm including farm section units (FSU), primary production units (PPU), secondary production units (SPU), redistribution units (RU), the household (HH), stocks (STOCK), and the external world (EXT) (see Van den Bosch et al. 1998; De Jager et al. 1998 for a full description). Land resources are described by FSUs which are land units that are considered homogeneous with well described characteristics. PPUs are the basic units of analysis and are defined as cropping activities of one or more crops in well defined fields over a specific period. One FSU can contain one or more PPUs. The animals present on the farm are described as SPUs which are groups of animals of the same species under similar management conditions in relation to e.g., feeding, grazing, and confinement. Locations within the farm where nutrients are accumulated and frequently reallocated (such as animal houses, corrals, fish ponds, dung hills, compost pits, latrines) are called the RUs. The HH is characterized by consumer and labor units including their gender, age distribution, and education as well as capital stocks. The STOCK is the temporary storage of crop products and residues, as well as other inputs. Finally, EXT comprises everything outside the farm limits including e.g., markets and neighboring farms.

Nutrient flows between the various compartments are being monitored and modeled. Nutmon considers five nutrient inputs: IN1 (inorganic fertilizers and feed concentrates), IN2 (organic feeds and organic materials), IN3 (atmospheric deposition), IN4 (nitrogen fixation), and IN5 (sedimentation), and five outflows: OUT1 (crop and animal products), OUT2 (plant/crop residues and manure), OUT3 (leaching), OUT4 (gaseous losses), and OUT5 (erosion and overland flow). Nutmon quantifies the various nutrient flows in two different ways (Van den Bosch et al. 1998). The so-called easy-to-quantify nutrient flows (IN1, IN2, OUT1, and OUT2) are directly assessed during a dynamic farm survey. Other hard-to-quantify flows (IN3, IN4, IN5, OUT3, OUT4, and OUT5) are estimated with regression models based on a 
literature review. The full nutrient balance is assessed as the difference between all inputs and outputs. Many research programs use the partial balance based on the easy-to-quantify flows (IN1 + IN2 OUT1 - OUT2). Although, this avoids the sometimes tedious estimation of the difficult-to-quantify nutrient flows, the interpretation of the partial balance is rather difficult as major nutrient flows are lacking from the analysis.

The approach to adapt Nutmon to South-East Asia

Although IAA farming systems in the MD do not compare with African farming systems, this does not inhibit the use of Nutmon and the calculation of partial balances. However, the estimation of the full soil nutrient balance requires the assessment of the difficult-to-quantify flows which are currently based on very specific African data. It was therefore necessary to adapt the regression models for the difficult-to-quantify flows on the basis of a literature review specific to the Mekong delta. We considered four alternative ways to assess difficult-to-quantify nutrient flows: (1) regression models remained unchanged when their contribution to the nutrient balance was expected to be of minor importance or when results were considered to be realistic, (2) an average value for a nutrient flow was applied when literature review reveals little variation, (3) a new regression model was assessed when literature review reveals variation related to some measured parameters, and (4) when literature review revealed variation but no logical pattern additional research was suggested. Through the above procedures Nutmon was adapted so that it provided reliable estimates for the MD.

Applying Nutmon to the IAA farming systems in the MD

The adapted Nutmon model was applied to the farm data to asses the soil nutrient balances for the three IAA systems in the MD. Balances were estimated at the farm level, but also for the various primary production units. The nutrient balances were used to evaluate nutrient emissions of the IAA system and formed the basis for a discussion on nutrient use efficiency of the IAA systems.

\section{Results}

Farm components and production

All farms had orchards (fruit trees), livestock (mainly pigs and poultry), and fish. The farms in the R-HF system focused on the production of rice and fish although some included orchards, livestock, and vegetables. The farms in the R-MF system focused on the production of rice but also included some fruit trees, vegetables, livestock, and fish. One farm in this system had leased out its rice field during the second year because of financial problems. The farms in the O-LF system focused on orchards. All four farms combined orchards with livestock and fish; one also included rice and vegetables. The main farm components were rice and fish in the R-HF system, rice in the R-MF system, and fruit trees in the O-LF system. Vegetables were more common in the R-MF system compared to the other two systems. Few goats and rabbits were present on one farm of each system.

In this study, the IAA farms in the MD were characterized using the conceptual model of Nutmon. The IAA farms can be subdivided into three major Primary Production Units that coincide with three distinct Farm Section Units: the rice fields, orchards with fish ponds, and vegetable fields. Four Secondary Production Units can be identified i.e., pigs, poultry, goats/rabbits, and fish. The fish pond is the only major RU. The households did not keep a significant STOCK which was therefore ignored in the subsequent analysis. Table 1 shows the average area and yields of the main PPUs. The farms in the R-HF system were significantly larger than of the other two systems and also more land is dedicated to rice and fish ponds. Areas assigned to orchards were similar in the three systems but fruit yields in the R-HF and O-LF systems were higher than in the R-MF system which had the highest rice yield. The lowest rice yield was in the O-LF system with only one farm cultivating rice on a small patch. The R-MF system had two rice crops per year in contrast to the R-HF system with only one cycle. As a result the rice yields for the R-MF system were almost double those of the $\mathrm{R}-\mathrm{HF}$ system. In the R-HF and R-MF systems vegetables were cultivated in small areas with various crops over the two monitored years. In the O-LF system one farm rotated vegetables with rice. The production of pigs and poultry per farm was relatively 
Table 1 Land use and annual yields of various farm components for the three systems in the MD (standard error between parentheses)

\begin{tabular}{|c|c|c|c|c|}
\hline & $\mathrm{R}-\mathrm{HF}$ & R-MF & O-LF & All farms \\
\hline Number of farms & 3 & 4 & 4 & 11 \\
\hline \multicolumn{5}{|l|}{ Land use } \\
\hline Orchard (ha) & $0.33(0.03)$ & $0.40(0.05)$ & $0.44(0.10)$ & $0.39(0.04)$ \\
\hline Rice (ha) & $2.05^{\mathrm{a}}(0.78)$ & $0.48^{\mathrm{b}}(0.06)$ & $0.08^{\mathrm{b}}(0.05)$ & $0.76(0.27)$ \\
\hline Vegetables (ha) & $0.02(0.01)$ & $0.04(0.01)$ & - & $0.02(0.01)$ \\
\hline Fish pond (ha) & $0.48^{\mathrm{a}}(0.08)$ & $0.15^{\mathrm{b}}(0.01)$ & $0.11^{\mathrm{b}}(0.02)$ & $0.23(0.04)$ \\
\hline Whole farm (ha) & $2.90^{\mathrm{a}}(0.86)$ & $1.16^{\mathrm{b}}(0.12)$ & $0.64^{\mathrm{b}}(0.09)$ & $1.45(0.30)$ \\
\hline \multicolumn{5}{|l|}{ Crop production* } \\
\hline Rice $\left(\mathrm{kg} \mathrm{ha}^{-1}\right.$ year $\left.^{-1}\right)$ & $5510^{\mathrm{a}, \mathrm{b}}(1776)$ & $10657^{\mathrm{a}}(2273)$ & $1159^{\mathrm{b}}(-)$ & 5799 (1298) \\
\hline Fruits $\left(\mathrm{kg} \mathrm{ha}^{-1}\right.$ year $\left.^{-1}\right)$ & $6014^{\mathrm{a}}(728)$ & $3206^{\mathrm{b}}(638)$ & $7215^{\mathrm{a}}(1135)$ & $5430(621)$ \\
\hline Vegetables $\left(\mathrm{kg} \mathrm{ha}^{-1}\right.$ year $\left.^{-1}\right)$ & $1188(1188)$ & $7721(3212)$ & $3949(2741)$ & $4567(1606)$ \\
\hline \multicolumn{5}{|l|}{ Animal production } \\
\hline Number of pigs & $10(8)$ & $16(3)$ & $7(2)$ & $11(3)$ \\
\hline Number of poultry & $196^{\mathrm{a}}(43)$ & $145^{\mathrm{a}, \mathrm{b}}(23)$ & $56^{\mathrm{b}}(13)$ & $126(19)$ \\
\hline Pig production $\left(\mathrm{kg}\right.$ year $\left.{ }^{-1}\right)$ & $2210(2020)$ & $1118(168)$ & $602(196)$ & $1228(541)$ \\
\hline Poultry production $\left(\mathrm{kg}\right.$ year $\left.^{-1}\right)$ & $286(75)$ & $297(83)$ & $109(37)$ & $226(42)$ \\
\hline Goats/Rabbit production $\left(\mathrm{kg}_{\text {year }}{ }^{-1}\right)$ & $4(4)$ & $5(5)$ & $3(3)$ & $4(2)$ \\
\hline Fish production $\left(\mathrm{kg} \mathrm{ha}^{-1}\right.$ year $\left.^{-1}\right)$ & $830^{\mathrm{a}}(302)$ & $480^{\mathrm{a}, \mathrm{b}}(98)$ & $200^{\mathrm{b}}(45)$ & $474(101)$ \\
\hline
\end{tabular}

Different superscripts $\left({ }^{\mathrm{a}, \mathrm{b}}\right)$ denote significant differences between means within rows $(P<0.05)$

$R-H F$ rice-based and high input fish system, $R-M F$ rice-based and medium input fish system, $O-L F$ orchard-based and low input fish system

* Crop production is expressed per ha of crop area; (-) in rotation with rice

high in the systems R-HF and R-MF compared to the O-LF system. The three systems have a similar area under fish pond (e.g., 17\% in R-HF, 13\% in R-MF, and $17 \%$ in $\mathrm{O}-\mathrm{LF})$, but their productions varied significantly $(P<0.05)$ because of differences in intensity of fish farming.

Although management differences between the crops and farms do exist, crop management was intensive with large quantities of mineral fertilizer of particularly nitrogen $(>100 \mathrm{~kg} / \mathrm{ha})$ but also $\mathrm{P}$ $(>20 \mathrm{~kg} / \mathrm{ha})$ and $\mathrm{K}(>10 \mathrm{~kg} / \mathrm{ha})$. In addition, there was significant input of nutrients to the farms in the form of feed concentrates.

Despite the differences in crop management no major difference in soil properties can be observed (Table 2). Available $\mathrm{P}$ is an exception with significantly higher contents in the R-HF system. The topsoil properties are used to calculate the nutrient stocks of the major primary production units in the systems (Table 3). The high nutrient stocks of the orchards are much larger than the stocks in the rice and vegetable systems because of differences in effective soil depth between the perennial trees and the annual crops $(50 \mathrm{~cm}$ vs. $30 \mathrm{~cm}$ ), and probably due to the lower nutrient uptake under the orchards in combination with litter deposition and minimal tillage.

Adapting Nutmon to Asian conditions

The estimation of the easy-to-quantify flows in Nutmon is universal and does not require any adaptations. The methods for the estimation of the difficult-to-quantify flows, however, require reconsideration. In this Section we present the procedures and adaptations per nutrient flow to make Nutmon suitable for Asian conditions.

\section{Atmospheric deposition (IN3)}

Atmospheric deposition includes both wet and dry deposition. Nutmon calculates wet deposition as a 
Table 2 Topsoil (0-20 cm depth) characteristics of the three systems in the MD

\begin{tabular}{lccc}
\hline Parameter & R-HF & R-MF & O-LF \\
\hline Soil pH & 5.1 & 4.6 & 4.3 \\
Soil organic matter (\%) & 3.94 & 4.90 & 4.00 \\
N Total (\%) & 0.20 & 0.20 & 0.17 \\
P Total (\%) & 0.16 & 0.19 & 0.16 \\
K Total (\%) & 1.36 & 1.48 & 1.35 \\
Available P (mg $\left.100 \mathrm{~g}^{-1}\right)$ & 10.12 & 6.96 & 2.94 \\
Exchangeable K $\left(\mathrm{meq} \mathrm{100} \mathrm{g}^{-1}\right)$ & 0.26 & 0.26 & 0.24 \\
Soil bulk density $\left(\mathrm{g} \mathrm{cm}^{-3}\right)$ & 1.08 & 1.02 & 0.93 \\
Sand (\%) & 1.17 & 0.97 & 1.04 \\
Clay (\%) & 55.78 & 50.69 & 53.55 \\
\hline
\end{tabular}

$R-H F$ rice-based and high input fish system, $R-M F$ rice-based and medium input fish system, $O-L F$ Orchard-based and low input fish system

function of annual precipitation. The literature provided few data points for nutrient inputs from wet deposition in Asia with inputs of $1.5 \mathrm{~kg} \mathrm{~N}$ (App et al. 1984), $0.25 \mathrm{~kg} \mathrm{P}$ (Carbo et al. 2005), and $8 \mathrm{~kg} \mathrm{~K} \mathrm{ha}^{-1}$ year $^{-1}$ (Hoa et al. 2006). Given the relatively low input of nutrients through IN3, we will use these values as fixed inputs for the MD. Dry deposition in the humid parts of Africa was considered to be of minor importance. This is probably also true for the humid MD. Dry deposition is therefore ignored.

\section{Nitrogen fixation (IN4)}

There are three types of $\mathrm{N}$ fixation: (1) nonsymbiotic $\mathrm{N}$ fixation through free-living bacteria occurring in almost all agricultural systems, (2) symbiotic $\mathrm{N}$ fixation through symbiotic bacteria (Rhizobia) in systems with leguminous crops, and (3) $\mathrm{N}$ fixation through Azolla and other algae in irrigated rice fields (Roy et al. 2003). We assumed that the non-symbiotic $\mathrm{N}$ fixation in dryland agriculture in the MD is similar to African conditions. In the IAA farms in the MD very few leguminous crops are grown limiting the importance of symbiotic $\mathrm{N}$-fixation. $\mathrm{N}$ fixation in irrigated systems should be included for rice fields in South-East Asia. According to Roger and Ladha (1992) N fixation in wetland rice fields can be estimated by various agents associating with the rice rhizosphere (1-7 kg N ha ${ }^{-1}$ crop $\left.^{-1}\right)$, rice straw (2-4 $\mathrm{kg} \mathrm{N} \mathrm{t}^{-1}$ straw), organic debris (1-31 kg N ha ${ }^{-1}$ crop $^{-1}$ ), blue-green algae $\left(0-80 \mathrm{~kg} \mathrm{~N} \mathrm{ha}^{-1} \mathrm{crop}^{-1}\right)$, azolla
Table 3 Average N, P and K soil stocks of Primary Production Units in the three systems in the MD $\left(\mathrm{kg} \mathrm{ha}^{-1}\right)$ (standard error in parentheses)

- in rotation with rice

$R-H F$ rice-based and high input fish system, $R-M F$ rice-based and medium input fish system, $O-L F$ orchard-based and low input fish system

* Only one farm

\begin{tabular}{lcccc}
\hline Nutrient & R-HF & R-MF & O-LF & All farms \\
\hline Orchard & & & & \\
N & $8405(661)$ & $9357(375)$ & $8647(282)$ & $8839(251)$ \\
P & $4641(354)$ & $8619(446)$ & $7361(797)$ & $7077(478)$ \\
K & $88947(5964)$ & $95953(4483)$ & $76992(3669)$ & $87147(3090)$ \\
Rice & & & & \\
N & $4943(285)$ & $3947(334)$ & $2421(1213)$ & $4019(332)$ \\
P & $3795(241)$ & $4132(559)$ & $2133(958)$ & $3721(375)$ \\
K & $24635(2169)$ & $26960(2049)$ & $19015(9836)$ & $25022(1835)$ \\
Vegetables & & & & \\
N & $3468^{*}$ & $4821(418)$ & - & $4551(422)$ \\
P & $1881^{*}$ & $4816(542)$ & - & $4229(722)$ \\
K & $38248^{*}$ & $34464(3062)$ & - & $35222(2490)$ \\
Fish pond & & & & $3842(279)$ \\
N & $4359(597)$ & $4102(548)$ & $3194(225)$ & $3631(371)$ \\
P & $4254(1288)$ & $3814(301)$ & $2982(215)$ & $28408(682)$ \\
K & $27971(616)$ & $30044(1177)$ & $27101(1265)$ & \\
\hline
\end{tabular}


(20-150 kg N ha ${ }^{-1} \mathrm{crop}^{-1}$ ), and green manure legumes (20-260 kg N ha $\left.{ }^{-1} \mathrm{crop}^{-1}\right)$. Those estimations were derived from separate measurements (Dalsgaard and Oficial 1998). Total N fixation in a rice field has not yet been estimated by measuring simultaneously the activities of the various components in situ. As a result, it is not clear if $\mathrm{N}$ fixation agents are independent or related (Roger and Ladha 1992). Roy et al. (2003) indicated that, although of the total $\mathrm{N}$ demand of low producing wetland rice (including naturally flooded and irrigated land) $80 \%$ can be supplied through $\mathrm{N}$ fixation, in most cases $\mathrm{N}$ fixation does not exceed $30 \mathrm{~kg} \mathrm{~N}^{-1}$ year $^{-1}$. With the high production levels in the MD, $30 \mathrm{~kg} \mathrm{~N} \mathrm{ha}^{-1}$ year $^{-1}$ from biological nitrogen fixation was used as an input for rice fields in the IAA farms.

\section{Sedimentation and irrigation (IN5)}

In the MD sedimentation takes place during the yearly flooding and mainly on low-laying rice fields. The sediment load depends on the source of flood water and is influenced by distance from rivers. At regional level the sedimentation from flooding can be an important source of nutrient inputs. However the studied IAA farms were surrounded with dikes to control flooding. Therefore, sediment input with flood water is unimportant. In IAA farms, nutrients also accumulate in the pond including residues from fish feed and sediment accumulated via exchange of river/ canal water. Nutrients in the fish pond sediment were estimated by monitored farm data. In the IAA farms fish pond sediment is considered as nutrient input for the orchard and vegetable fields, which is quantified as product of pond area and pond sediment divided by total orchard and vegetable area. We only considered nutrient inputs from irrigation water in the nutrient balance calculation. In IAA farms the fruit trees and vegetables are irrigated with a frequency of 3 days in the dry season (i.e., 6 months). Based on Nhan et al. (2006) and Hoa et al. (2006), irrigation water in IAA farms is estimated to contribute $1.8 \mathrm{~kg} \mathrm{~N}, 2.4 \mathrm{~kg} \mathrm{P}$, and $1.2 \mathrm{~kg} \mathrm{~K} \mathrm{ha}^{-1}$ year $^{-1}$. For one rice crop (i.e., 3 months) the irrigation water supplies $2.7 \mathrm{~kg} \mathrm{~N}, 3.6 \mathrm{~kg} \mathrm{P}$, and $1.8 \mathrm{~kg} \mathrm{~K} \mathrm{ha}^{-1}$.
Leaching of $N, P$ and $K$ in paddy and upland soils (OUT3)

Land preparation and intensive rice farming with large amounts of fertilizer on clayey paddy fields can influence the rates of leaching and gaseous losses. In Nutmon, Nitrogen leaching on dry land farming systems in Sub-Saharan Africa is based on soil texture and rainfall (Smaling et al. 1993). Application of the African regression models will overestimate $\mathrm{N}$ leaching for paddy soils in South-East Asia. Various values of leaching and gaseous losses of $\mathrm{N}$ in paddy soils corresponding to their rates of $\mathrm{N}$ fertilizer application, soil types, and study locations were collected for Asian countries (Table 4). Leaching of $\mathrm{N}$ in these systems varied from 0.1 to $9 \%$ of applied $\mathrm{N}$ fertilizer (Fig. 1a). Leaching values showed a weak relationship with $\mathrm{N}$ fertilizer rates $\left(r^{2}=0.12\right)$. Therefore an average leaching rate of $6 \mathrm{~kg} \mathrm{~N} \mathrm{ha}^{-1}$ year $^{-1}$ is used in paddy soils.

Literature showed that $\mathrm{N}$ leaching amounted to $49 \%$ of the $\mathrm{N}$ fertilizer applied in soils with a rotation of annual upland crops (Table 4; Fig. 1c). Leaching of $\mathrm{N}$ ( $\mathrm{N}_{\text {leaching }}$ ) is strongly related to the application of inorganic nitrogen fertilizer $\left(\mathrm{N}_{\text {fertilizer }}\right)$ yielding the following equation:

$\mathrm{N}_{\text {leaching }}=0.37 \mathrm{~N}_{\text {fertilizer }}+20.7\left(r^{2}=0.97\right)$

Studies on $\mathrm{N}$ leaching in orchard soils are rare in South-East Asia. We propose to use the above equation for estimation of $\mathrm{N}$ leaching in upland soils in the MD. Leaching of $\mathrm{K}$ in upland soil with a ricewheat rotation (Fan et al. 2005) amounted to 3\% of the $\mathrm{K}$ fertilizer applied. In the MD $\mathrm{K}$ leaching was also estimated at about 3\% (Table 4) of $\mathrm{K}$ fertilizer applied on acid sulfate soil (Hoa et al. 2006). The adapted model uses this value.

In tropical soils, soil particles bind $\mathrm{P}$ tightly. For example small $\mathrm{P}$ leaching from 0.071 to $0.11 \mathrm{~kg} \mathrm{P} \mathrm{ha}^{-1}$ year $^{-1}$ was measured under rice and wheat rotation on Gleyi-stagnic Anthrosols, with an application of $60-300 \mathrm{~kg} \mathrm{P} \mathrm{ha}^{-1}$ year $^{-1}$, using a large-scale lysimeter (Shan et al. 2005). Cho et al. (2002) estimated that losses of $\mathrm{P}$ in the paddy soil through leaching were only $0.2-0.3 \%$ to the amount of $\mathrm{P}$ applied. Therefore, $\mathrm{P}$ leaching is considered unimportant (Roy et al. 2003). 
Table 4 Annual fertilizer rates, leaching values of $\mathrm{N}$ and $\mathrm{K}$, and gaseous losses in paddy soils and upland soils in some Asian countries

\begin{tabular}{|c|c|c|c|c|c|}
\hline Items & Soil types/land uses & Leaching $^{\mathrm{a}}$ & Fertilizer $^{\mathrm{a}}$ & Locations & Sources \\
\hline \multicolumn{6}{|l|}{ Leaching of $\mathrm{N}$} \\
\hline \multirow[t]{7}{*}{ Paddy soil } & Transplanted rice & $0.2-3.5$ & $201-258$ & Cauvery Delta, India & Pampolino et al. (2007) \\
\hline & $\begin{array}{l}\text { Transplanted and } \\
\text { broadcasted rice }\end{array}$ & $0.9-1.2$ & $225-249$ & Nueva Ecija, Philippines & Pampolino et al. (2007) \\
\hline & Broadcasted rice & $0.1-0.3$ & $174-224$ & Mekong Delta, Vietnam & Pampolino et al. (2007) \\
\hline & Fluventic Haplaquepts & $9-11.9$ & $122-140$ & Maryung-myun, Korea & Yoon et al. (2006) \\
\hline & Inceptions & 0.7 & 120 & New Delhi, India & $\begin{array}{l}\text { Bandyopadhyay and } \\
\text { Sarkar (2005) }\end{array}$ \\
\hline & NA & 10.6 & 345 & Jiangsu, China & $\begin{array}{l}\text { Ma et al. (1997) cited by } \\
\text { Xing \& Zhu (2000) }\end{array}$ \\
\hline & NA & 27 & 300 & Zhejiang, China & $\begin{array}{l}\text { Wang et al. } 1996 \text { cited } \\
\text { by Xing \& Zhu, } \\
\text { (2000) }\end{array}$ \\
\hline \multirow[t]{5}{*}{ Upland soil } & Hillside, silty clay loam & $41-56$ & 61 & Na Haew, Thailand & Pansak et al. (2005) \\
\hline & $\begin{array}{l}\text { Clayey soil. Maize } \\
\text { inter-cropped with } \\
\text { soybean, and sweet } \\
\text { potato }\end{array}$ & 140 & 309 & Nongshi & Liang et al. (2005) \\
\hline & & 234 & 540 & Nongli & Liang et al. (2005) \\
\hline & & 178 & 461 & Patan & Liang et al. (2005) \\
\hline & & 121 & 297 & Waixain & Liang et al. (2005) \\
\hline \multicolumn{6}{|l|}{ Leaching of $\mathrm{K}$} \\
\hline Paddy soil & Acid sulfate soil & $1-2$ & $40-70$ & Mekong Delta, Vietnam & Hoa et al. (2006) \\
\hline Upland soil & $\begin{array}{l}\text { Fluvaquent, rice-wheat } \\
\text { rotations }\end{array}$ & $3-4$ & 125 & Chengdu Plain, China & Fan et al. (2005) \\
\hline \multicolumn{6}{|c|}{ Gaseous loss of $\mathrm{N}$} \\
\hline \multirow[t]{6}{*}{ Paddy soil } & Transplanted rice & $88-148$ & $201-258$ & Cauvery Delta, India & Pampolino et al. (2007) \\
\hline & $\begin{array}{l}\text { Transplanted and } \\
\text { broadcasted rice }\end{array}$ & $102-139$ & $225-249$ & Nueva Ecija, Philippines & Pampolino et al. (2007) \\
\hline & Broadcasted rice & $75-150$ & $174-224$ & Mekong Delta, Vietnam & Pampolino et al. (2007) \\
\hline & Inceptisol & 21 & 120 & New Delhi, India & $\begin{array}{l}\text { Bandyopadhyay and } \\
\text { Sarkar, (2005) }\end{array}$ \\
\hline & Tropaqualf & 71 & 150 & IRRI, Philippines & Belder et al. (2005) \\
\hline & Tropaqualf & 52 & 150 & IRRI, Philippines & Belder et al. (2005) \\
\hline \multirow[t]{5}{*}{ Upland soil } & $\begin{array}{l}\text { Alluvial soil. Rice- } \\
\text { barley rotations }\end{array}$ & $24-43$ & 64 & Ariake Bay, Japan & $\begin{array}{l}\text { Shiratani and } \\
\text { Yoshimaga (2005) }\end{array}$ \\
\hline & $\begin{array}{l}\text { Clayey soil. Maize } \\
\text { inter-cropped with } \\
\text { soybean, and sweet } \\
\text { potato }\end{array}$ & 166 & 309 & Nongshi & Liang et al. (2005) \\
\hline & & 288 & 540 & Nongli & Liang et al. (2005) \\
\hline & & 237 & 461 & Patan & Liang et al. (2005) \\
\hline & & 159 & 297 & Waixain & Liang et al. (2005) \\
\hline
\end{tabular}

a in $\mathrm{kg} \mathrm{ha}^{-1}$ year $^{-1}$

NA not available 
Fig. 1 Nitrogen losses in relation with varying rates of $\mathrm{N}$ fertilizer based on literature data a) leaching in paddy soils, b) gaseous losses in paddy soils, c) leaching in upland soils, and d) gaseous losses in upland soils (a)

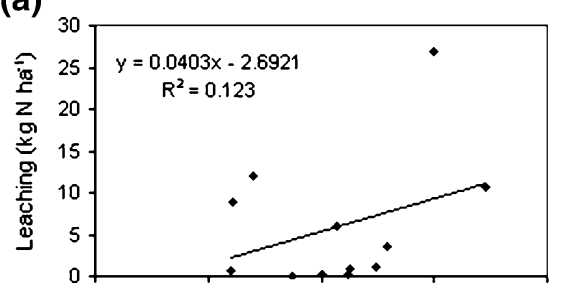

(c)

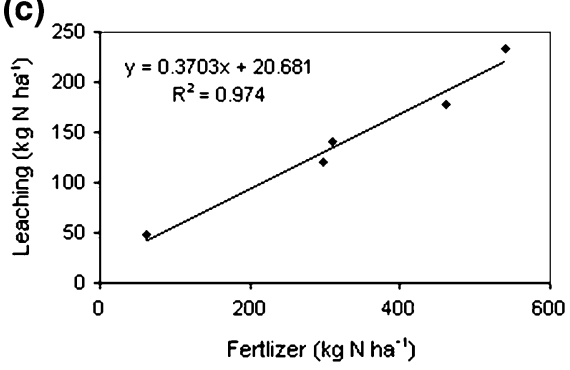

(b)

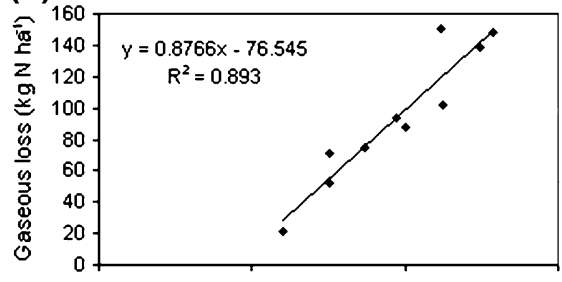

(d)

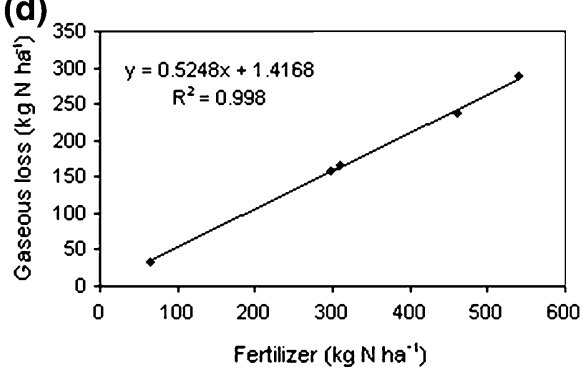

Gaseous losses in paddy and upland soils (OUT4)

Table 4 shows a range of experiments from Asian countries with measurements of gaseous $\mathrm{N}$ losses in paddy soils with varying rates of $\mathrm{N}$ fertilizer application, soil types, and study locations. $\mathrm{N}$ is lost to the atmosphere by two processes: denitrification and volatilization. Denitrification losses are expected to be greatest in wet climates, on highly fertilized, clayey soils, and for crops that withdraw relatively small amounts of N. Ammonia volatilization plays a role mainly in alkaline environments (Roy et al. 2003) which are not present in the MD with an average soil $\mathrm{pH}$ of 4.7 (Table 2) and an average $\mathrm{pH}$ of pond water of 6.7 (Nhan et al. 2006). On average, gaseous losses amounted up to $48 \%$ of $\mathrm{N}$ fertilizer application (Fig. 1b). Almost 90\% of variation in gaseous losses $\left(\mathrm{N}_{\text {gaseous }}\right)$ can be explained by fertilizer rates. In Nutmon-Asia, we used a regression equation to estimate the gaseous losses in paddy soils:

$\mathrm{N}_{\text {gaseous,paddy }}=0.88 \mathrm{~N}_{\text {fertilizer }}-76.5$

Studies on gaseous losses of $\mathrm{N}$ in orchard soils are rare in South-East Asia. From literature we found a very strong relationship $\left(r^{2}=0.998\right)$ between $\mathrm{N}$ fertilizer rates and gaseous losses in upland soil indicating a 53\% loss. These gaseous losses can be predicted by equation (Fig. 1d):
$\mathrm{N}_{\text {gaseous, orchard }}=0.52 \mathrm{~N}_{\text {fertilizer }}+1.4$

In addition burning crop residues cause almost complete $\mathrm{N}$ loss, $\mathrm{P}$ losses of about $25 \%$ and $\mathrm{K}$ losses of $20 \%$. The amount of nutrients lost depends on the method used to burn the straw. In areas where harvesting has been mechanized, all the straw remains in the field and is rapidly burned in situ; therefore, losses of $\mathrm{P}$ and $\mathrm{K}$ are small (Dobermann and Fairhurst 2000). Burning rice straw is practiced in the MD. In this study, burning of rice straw was observed and has been measured directly. Remaining rice straw was treated as an internal flow in the farms.

\section{Erosion (OUT5)}

Because all IAA farms in this study are located in completely flat areas we believe the erosion of the farm land is unimportant.

In summary, the hard-to-quantify flows were adjusted in Nutmon-Asia using methods as indicated in Table 5.

Application of Nutmon-Asia to MD farming systems

\section{Farm nutrient balances}

Table 6 shows positive nutrient balances for the IAAfarms in all three systems. Nutrient balances are 
Table 5 Methods for the estimation of nutrient inputs and outputs in Nutmon-Asia

\begin{tabular}{|c|c|c|c|c|}
\hline \multirow[t]{2}{*}{ Flows } & \multirow[t]{2}{*}{ Description } & \multicolumn{3}{|l|}{ Adapted value/Nutmon } \\
\hline & & $\mathrm{N}$ & $\mathrm{P}$ & $\mathrm{K}$ \\
\hline \multicolumn{5}{|l|}{ Inputs } \\
\hline IN1 & Inorganic fertilizers, feed concentrates & Farm data & Farm data & Farm data \\
\hline IN2 & Organic inputs & Farm data & Farm data & Farm data \\
\hline IN3 & Atmospheric deposition & $1.5 \mathrm{~kg} \mathrm{~N} \mathrm{ha}^{-1}$ year $^{-1}$ & $0.25 \mathrm{~kg} \mathrm{P} \mathrm{ha}^{-1}$ year $^{-1}$ & $8 \mathrm{~kg} \mathrm{~K} \mathrm{ha}^{-1}$ year $^{-1}$ \\
\hline \multirow[t]{3}{*}{ IN4 } & Nitrogen fixation & & & \\
\hline & Rice & $30 \mathrm{~kg} \mathrm{~N} \mathrm{ha}^{-1}$ year $^{-1}$ & Nutmon & Nutmon \\
\hline & Other crops & Nutmon & Nutmon & Nutmon \\
\hline \multirow[t]{3}{*}{ IN5 } & Irrigation & & & \\
\hline & Rice & $2.7 \mathrm{~kg} \mathrm{~N} \mathrm{ha}^{-1}$ year $^{-1}$ & $3.6 \mathrm{~kg} \mathrm{P} \mathrm{ha}^{-1}$ year $^{-1}$ & $1.8 \mathrm{~kg} \mathrm{~K} \mathrm{ha}^{-1}$ year $^{-1}$ \\
\hline & Other crops & $1.8 \mathrm{~kg} \mathrm{~N} \mathrm{ha}^{-1}$ year $^{-1}$ & $2.4 \mathrm{~kg} \mathrm{P} \mathrm{ha}^{-1}$ year $^{-1}$ & $1.2 \mathrm{~kg} \mathrm{~K} \mathrm{ha}^{-1}$ year $^{-1}$ \\
\hline \multicolumn{5}{|l|}{ Outputs } \\
\hline OUT1 & Farm products & Farm data & Farm data & Farm data \\
\hline OUT2 & Organic outputs & Farm data & Farm data & Farm data \\
\hline \multirow[t]{3}{*}{ OUT3 } & Leaching & & & \\
\hline & Paddy soils & $6 \mathrm{~kg} \mathrm{ha}^{-1}$ year $^{-1}$ & Nutmon & Nutmon \\
\hline & Orchard soils & Regression model & Nutmon & $3 \%$ of applied $\mathrm{K}$ \\
\hline \multirow[t]{3}{*}{ OUT4 } & Gaseous losses & & & \\
\hline & Paddy soils & Regression model & Nutmon & Nutmon \\
\hline & Orchard soils & Regression model & Nutmon & Nutmon \\
\hline OUT5 & Erosion & $0 \mathrm{~kg} \mathrm{ha}^{-1}$ year $^{-1}$ & $0 \mathrm{~kg} \mathrm{ha}^{-1}$ year $^{-1}$ & $0 \mathrm{~kg} \mathrm{ha}^{-1}$ year $^{-1}$ \\
\hline
\end{tabular}

dominated by the large inputs of nutrients through mineral fertilizer and feed. In the rice-based systems (R-HF) more nutrients leave the system through crop products compared to the R-MF and O-LF systems. A very small fraction of nutrient outputs leaves the system as crop products. Much more important is the output of nutrients through leaching and gaseous losses. $\mathrm{N}$ fixation was significantly higher in the rice based systems. The N, P and K from irrigation water were higher in the rice-based systems because of the importance of irrigation.

Nutrient outflows through animal products in the systems R-HF and O-LF were not much different. However, the outflow of $\mathrm{N}$ from animal products in the R-MF system was almost double compared to that in the $\mathrm{R}$-HF system. There was no nutrient export of livestock manure from the farms. Manure from pigs was used as input to the ponds and manure from poultry was left in the orchards and farm yards because of free ranging. The highest $(P<0.05)$ leaching of $\mathrm{N}$ was in the O-LF system. This could result from the high amount of inorganic fertilizer applied, and strong leaching in the upland soil under orchards. The gaseous losses of $\mathrm{N}$ were also high in the O-LF system. Balances of $\mathrm{P}$ and $\mathrm{K}$ were similar due to small quantities of nutrients involved. The highest $(P<0.05)$ surplus of $\mathrm{K}$ was also found in the O-LF system.

\section{Balances for the different cropping systems}

Table 7 compares partial and full nutrient balances of the main crops in the three systems. A positive partial and full balance of $\mathrm{N}$ and $\mathrm{P}$ was found for all crops except the $\mathrm{N}$ full balance of vegetables in the R-MF system. The partial and full balances of $\mathrm{K}$ for rice were negative in all three systems except the $\mathrm{K}$ full balance in the R-MF system. For orchards, the $\mathrm{N}$ partial balance was relatively high in the O-LF system as were the partial and full balance of $\mathrm{K}$ in the R-MF system.

For all farms, total $\mathrm{N}$ input of rice was high (273 $\mathrm{kg} \mathrm{ha}^{-1}$ ) compared to vegetables $\left(190 \mathrm{~kg} \mathrm{ha}^{-1}\right)$, and orchards $\left(123 \mathrm{~kg} \mathrm{ha}^{-1}\right)$. However, the small full balance of $\mathrm{N}$ in rice fields resulted from a large amount 


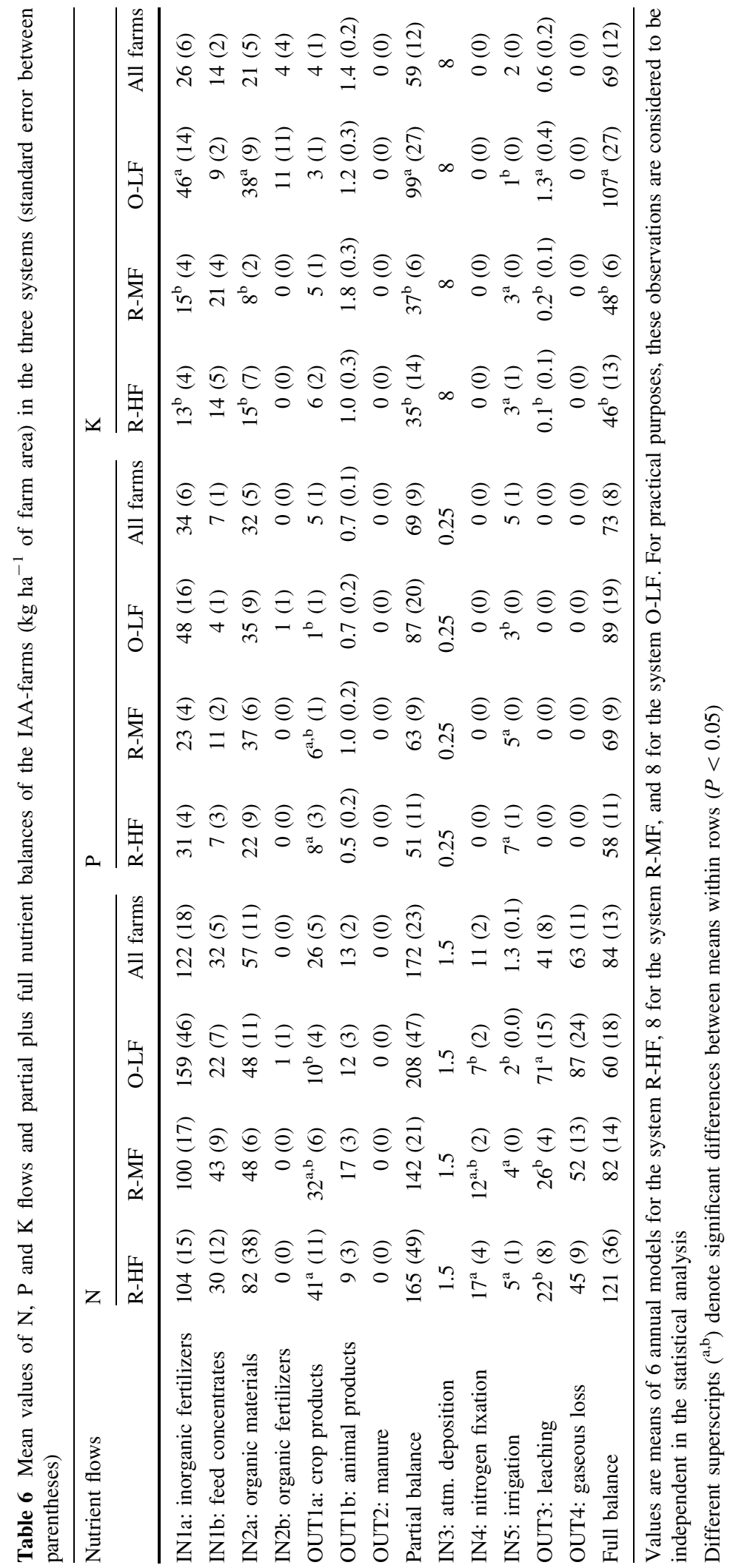


Table 7 Nutrient balances of crops ( $\mathrm{kg} \mathrm{ha}^{-1}$ of field area) in the three systems (standard error between parentheses)

\begin{tabular}{|c|c|c|c|c|c|c|c|c|c|c|c|c|}
\hline \multirow[t]{2}{*}{ Nutrient balance } & \multicolumn{4}{|l|}{$\mathrm{N}$} & \multicolumn{4}{|l|}{$\mathrm{P}$} & \multicolumn{4}{|l|}{ K } \\
\hline & R-HF & $\mathrm{R}-\mathrm{MF}$ & O-LF & Overall & R-HF & R-MF & O-LF & Overall & $\mathrm{R}-\mathrm{HF}$ & R-MF & O-LF & Overall \\
\hline \multicolumn{13}{|l|}{ Rice } \\
\hline Partial balance & $62(25)$ & $105(33)$ & 169 (16) & $102(21)$ & $23(8)$ & $16(11)$ & 107 (22) & $32(11)$ & $-60(25)$ & $-4(9)$ & $-75(43)$ & $-32(13)$ \\
\hline Full balance & $32(15)$ & $25(13)$ & $32(60)$ & $28(11)$ & $34(8)$ & $27(12)$ & $111(22)$ & $42(11)$ & $-47(25)$ & $10(9)$ & $-65(43)$ & $-19(13)$ \\
\hline \multicolumn{13}{|l|}{ Orchard } \\
\hline Partial balance & $99(39)$ & $53(20)$ & $132(32)$ & $94(18)$ & $34(13)$ & $18(6)$ & $40(9)$ & $30(6)$ & $169(96)$ & $13(5)$ & $56(15)$ & $71(28)$ \\
\hline Full balance & $61(36)$ & $2(14)$ & $35(16)$ & $30(13)$ & $37(13)$ & $20(6)$ & $43(9)$ & $33(6)$ & $178(96)$ & $22(4)$ & $64(12)$ & $80(29)$ \\
\hline \multicolumn{13}{|l|}{ Vegetables } \\
\hline Partial balance & $125(-)$ & $88(41)$ & $305(34)$ & $141(41)$ & $125(-)$ & $29(12)$ & $109(39)$ & $57(18)$ & $1498(-)$ & $101(66)$ & $170(85)$ & $272(160)$ \\
\hline Full balance & $91(-)$ & -23 (19) & $1(1)$ & $-4(17)$ & $128(-)$ & $31(12)$ & $112(39)$ & $60(18)$ & $1507(-)$ & $110(66)$ & $176(84)$ & $280(160)$ \\
\hline
\end{tabular}

Values are means of 6 annual models for the system R-HF, 8 for the system R-MF, and 8 for the system O-LF

- , only one farm

of harvested rice grain $\left(97 \mathrm{~kg} \mathrm{~N} \mathrm{ha}^{-1}\right)$ and large gaseous losses of $\mathrm{N}\left(106 \mathrm{~kg} \mathrm{ha}^{-1}\right)$. Furthermore, crop residues were removed from the fields $\left(36 \mathrm{~kg} \mathrm{~N} \mathrm{ha}^{-1}\right)$ as hygiene measure in crop rotation (e.g., the O-LF). The low $\mathrm{P}$ surplus of rice (Table 7) was caused by harvested grain and crop residue removal. Total $\mathrm{K}$ input for rice was high $\left(136 \mathrm{~kg} \mathrm{ha}^{-1}\right)$ whereas total $\mathrm{K}$ loss due to crop residue removal was quite high (129 $\mathrm{kg} \mathrm{ha}^{-1}$ ), which led to negative partial and full balances of $\mathrm{K}$ in rice (Table 7). The $\mathrm{N}$ full balance of orchards was mainly affected by weeds/grasses removed $\left(20 \mathrm{~kg} \mathrm{ha}^{-1}\right), \mathrm{N}$ leaching $\left(41 \mathrm{~kg} \mathrm{ha}^{-1}\right)$, and gaseous loss $\left(30 \mathrm{~kg} \mathrm{~N}^{-1}\right)$. The $\mathrm{P}$ full balance in the orchards was quite high $\left(33 \mathrm{~kg} \mathrm{ha}^{-1}\right)$ when compared to its total inputs ( $35 \mathrm{~kg} \mathrm{ha}^{-1}$ ) because of small output of $\mathrm{P}$ via harvested fruits. The $\mathrm{K}$ full balance was relatively high in the orchards because of high inputs of crop residue (e.g., rice straw) used to mulch the orchard beds (e.g., the R-HF). The relatively high $\mathrm{K}$ partial and full balance in the vegetable fields was impacted by a large storage of rice straw (e.g., 11 tons) on vegetable beds in the R-HF system.

The $\mathrm{N}$ full balance of fish ponds $\left(52 \mathrm{~kg} \mathrm{ha}^{-1}\right)$ in the R-MF system was caused by high input of organic materials (e.g., human excreta from a latrine pond), and the $\mathrm{N}$ full balance in the O-LF system was small because of low input of feed $\left(10 \mathrm{~kg} \mathrm{ha}^{-1}\right)$ in this extensive fish farming system. In the O-LF system the $\mathrm{P}$ full balance was small in fish production compared to the other two systems. A positive $\mathrm{K}$ full balance of $14 \mathrm{~kg} \mathrm{ha}^{-1}$ in fish production was found in the R-HF system. Fish ponds are considered as redistribution units. Through feeding the fish with inputs from outside nutrients are brought into the system and also leave the system via fish and sediment. For all farms in the three systems, the annual contribution was $16 \mathrm{~kg} \mathrm{~N}$ and $5.5 \mathrm{~kg} \mathrm{P} \mathrm{ha}^{-1}$ of farm area. Accumulation of $\mathrm{K}$ in fish pond sediment was not considered as there were no data available.

\section{Discussion}

Adapting Nutmon in the MD

Adaptation of Nutmon resulted in major changes in the calculation procedures for various flows. NutmonAsia takes into account many different activities influencing nutrient stocks (Tables 2,3) and flows on the farms, and produces information for a more efficient use of nutrients on the different crops and animals in the IAA farms in the MD.

Rice and orchards were the most important components of the IAA farms because of their large share of the farm area (Table 1). Vegetables were commonly grown on small areas, mainly for household consumption. In many farms soils under vegetables were comparable to those under orchards as farmers combined their orchard and vegetables areas. Therefore, the estimation of $\mathrm{N}$ losses in Nutmon-Asia (Fig. 1) were focused on paddy and orchard soils. Hung et al. (1995) stated that leaching was not an important loss mechanism in rice soils in the MD. N 
losses in paddy soil were presumed important but due to gaseous losses, not leaching.

Soil material used to build the orchard beds may be turned over during fertilization and soil aeration. The raised beds were surrounded by water in ditches that were used for irrigation and fish culture. These ditches can saturate part of the soil beds, especially in the wet season when water levels are high. In the dry season the ditches can be drained to control tree flowering. The alternate drying and wetting of the orchard soils in the MD in combination with the fine soil textures and low soil pH (Nguyen et al. 2006) make them special in comparison to other upland soils with annual crops in the literature. The specific characteristics can enhance the release of $\mathrm{N}_{2} \mathrm{O}$ and $\mathrm{NO}$ to the atmosphere (FAO 2001) and result in very different leaching and gaseous losses.

In crop production of IAA-farms $68 \%$ of the fertilizers were compound. $29 \%$ of the farms used urea. Compound fertilizers can lead to different gaseous losses when compared to single urea. Although gaseous losses result from volatilization and from denitrification, the literature only reported total gaseous $\mathrm{N}$ losses.

Nutmon-Asia may underestimate farm scale nutrient flows in some ways: (1) internal nutrients transferred to the household and part of the nutrients using for growth of animals are eventually exported from the farm; (2) part of the nutrients is used for the standing biomass of the trees (Dalsgaard and Oficial 1998) but is not captured in the model; (3) losses of $\mathrm{N}$ in orchard soils in the MD can differ from upland soils in other Asian countries because of specific soil management, e.g., groundwater level control; (4) flows of nutrients out of the farms through the death of animal are not taken into account, and modifications in the quantity of fish (birth, death, sales, and transfer) is difficult to monitor; (5) off-field gaseous losses are not considered, and losses of nutrients from a fish pond through diffusion processes are not taken into account by the model.

The effect of farm management on the soil nutrient balance

Crop selection can also affect the nutrient balances. In the O-LF system, fruits were the main crop (Table 1). Fruits have commonly low nutrient and dry matter contents (FAO 1972; FNRI 1990) which led to low nutrient outputs (Table 6). This has also been found in Northern Vietnam where a high surplus of nutrients $\left(85-882 \mathrm{~kg} \mathrm{~N} \mathrm{ha}^{-1}\right.$ year $^{-1}, 109-196 \mathrm{~kg}$ $\mathrm{P} \mathrm{ha}^{-1}$ year $^{-1}$, and $20-306 \mathrm{~kg} \mathrm{~K} \mathrm{ha}^{-1}$ year $^{-1}$ ) was recorded in vegetable farming systems (Khai et al. 2007). In this study relatively high $P$ and $K$ surpluses were found in vegetable production (Table 7). The full balance of $\mathrm{N}$ in vegetable fields was negative due to high leaching. Gaseous losses were not considered in the study in Northern Vietnam. Rice biomass in the two rice-based systems contributed importantly to farm production (Tables 1, 6). A farm producing three rice crops per year is expected to have a lower nutrient excess than a farm with two crops. For example, total annual mineral fertilizer application by MD farmers with three crops was about $200 \mathrm{~kg} \mathrm{~N} \mathrm{ha}^{-1}, 55 \mathrm{~kg} \mathrm{P} \mathrm{ha}^{-1}$, and $67 \mathrm{~kg} \mathrm{~K} \mathrm{ha}^{-1}$ with a total yield of 11 tons ha ${ }^{-1}$ (Huan et al. 2005). In our IAA farms the annual fertilizer applied per ha for rice was $209 \mathrm{~kg} \mathrm{~N}, 62 \mathrm{~kg} \mathrm{P}$, and $29 \mathrm{~kg} \mathrm{~K}$ but the total yield was only 5.8 tons $\mathrm{ha}^{-1}$. Intensive $\mathrm{N}$ and $\mathrm{P}$ fertilization in combination with relatively low yields resulted in a larger surplus in the rice fields of the IAA farms. Low $\mathrm{K}$ fertilization for rice was the main reason for the negative balance of $\mathrm{K}$ as shown in Table 7 (Hoa et al. 2006).

Annual $\mathrm{N}$ fertilization was much higher for rice (209 $\mathrm{kg} \mathrm{N} \mathrm{ha}^{-1}$ ) and vegetables (144 $\mathrm{kg} \mathrm{N} \mathrm{ha}^{-1}$ ) than fruit trees $\left(55 \mathrm{~kg} \mathrm{ha}^{-1}\right)$. The farmers applied nutrients on a regular basis but disregarded nutrient balances of the farm due to the lack of appropriate information. The high surplus of nutrients in the three systems (Table 6) implies an accumulation of nutrients within the soil pools. The results certainly indicate that farmers were over-fertilizing. Normally farmers intuitively decided how much fertilizer to apply. They did not consider N, P and K contents in fertilizer nor in the soil. This may lead to excess fertilizer applications and imbalances in the soil.

Animal feed accounted for 42,53 and $60 \%$ of the $\mathrm{N}, \mathrm{P}$ and $\mathrm{K}$ farm inputs (e.g., fertilizers and feeds), respectively (Table 6). Purchased feeds (e.g., concentrates, rice and bran) contributed to a nutrient surplus in animal production in all three systems. In terms of nutrient surpluses, pig production was more intensive than poultry or fish in all three systems. Pigs were considered important for saving money whereas poultry was mainly used for household consumption. The pattern of livestock production 
caused fluctuations in the numbers of animals kept on the farms. Consequently, feed use varied over the year affecting nutrient use efficiencies.

Animal manure can contribute to nutrient recycling (De Ridder and Van Keulen 1990). Pig manure was frequently used as input to the fish ponds to reduce the purchase of external feed for fish. The use of pig manure can cause pollution of the ponds (Nhan et al. 2007). Poultry drops their manure mainly on orchard beds where it decomposes. It was estimated that annually $32 \mathrm{~kg} \mathrm{~N}, 14 \mathrm{~kg} \mathrm{P}$ and $10 \mathrm{~kg} \mathrm{~K} \mathrm{ha}^{-1}$ from poultry manure were left to decompose in the orchards.

Family, crop and livestock waste accumulated in the fish pond of IAA farms. These nutrients were recycled by using sediment to cover orchard beds and vegetable fields (Muendo, 2006). However due to labour shortage, this was not done on a yearly basis in the IAA farms. Sediment accumulation in the ponds depends on the intensity of exchange with surface water. A low water exchange rate in the R-MF system resulted in low nutrient losses (Nhan et al. 2007). Amounts of $\mathrm{N}$ and $\mathrm{P}$ from the pond sediments were small compared to the inputs of inorganic fertilizer.

How to achieve a neutral balance in the IAA systems?

Nutrient surpluses accumulate within the soil pools and improve soil fertility but may also pose a threat for environmental contamination (Nielsen and Kristensen 2005). Given the relatively high inherent soil fertility in the MD, one should aim for a (near) neutral nutrient balance which can be achieved through better use of on-farm resources and a reduction of external inputs.

The positive soil nutrient balances indicate that farmers were over-fertilizing. To reduce the risk of contamination but also to increase the returns of the farms, the results suggest that the IAA farms can lower the application of mineral fertilizers. IAA farms mainly use inorganic fertilizers. The application of organic fertilizers was rare due to labour shortage for composting, fluctuating number of animals on the farms, and the slow response of organic fertilizers according to the farmers. In the R-MF system, for instance, rice straw could be used to compost or mulch the orchard beds or vegetable fields instead of burning. In the three systems pig manure, instead of direct use in the fish ponds can also be used to raise earthworms to feed fish (Mason et al. 1992), and the residues then can be used as fertilizer. Keeping the soil covered with crop residues in the farms reduces runoff, and enhances the soil organic matter (Powel and Unger 1997).

Farmers sometimes acted impulsively when applying fertilizers. In the O-LF system a water melon disease occurred in the second crop when a farmer applied $42 \mathrm{~kg} \mathrm{~N}$ but harvested only 6 tons of fruit $\mathrm{ha}^{-1}$ compared to $25 \mathrm{~kg} \mathrm{~N}$ for 14 tons of fruit ha ${ }^{-1}$ in the first crop. Market price fluctuations in the MD (Phong et al. 2008) also impact farmer decision to fertilizer crops, especially in the case of fruit trees. For example, three farmers (one in each system) did not fertilize their orchards because of financial constraints.

The interpretation of the nutrient balances can be further improved by linking the farm nutrient budgets with total soil nutrient stocks (Van den Bosch et al. 1998). Data collection for reliable parameterization of the model was time-consuming. The analysis presented in this paper allows for a screening of important processes where future research can focus on. In this cases $\mathrm{N}$ losses from the orchard soils through leaching and gaseous losses requires specific attention. In this study, farm data were monitored and measured. However, nutrient contents of farm materials were based mainly on the literature because of many different farm materials to be used, and due to manpower and financial constraints in sample analysis. Although, data from Asia and the MD were used, nutrient contents in farm outputs can vary with different levels of farms intensification (e.g., amount of $\mathrm{N}$ applied). Therefore future studies may evaluate this variation and see whether specific sampling at each of the farms is required.

\section{Interpretation of soil nutrient balances}

The paper has shown that it is important to adapt the Nutmon model to the local conditions through the regions-specific assessment of the hard-to-quantify flows. However, as indicated in the results and discussion, the results of this type of analysis remain to be used as an indicator to compare different systems and identify elements of the farming system where nutrient management can be improved. Detailed modeling or measurements of 
all hard-to-quantify nutrient is virtually impossible and to the authors' knowledge never accomplished on a single farm.

\section{Conclusions}

This study provides a structured way to adapt the calculation of the hard-to-quantify flows in Nutmon to local conditions. Nutmon was adapted for the IAA systems found in Asia and applied to the MD. Although there was considerable variation between the various systems in the MD, nutrient surpluses were found. The surpluses indicate that farmers were over-fertilizing and suggest a low nutrient use efficiency. The IAA farms in the three fish input systems certainly maintain their soil fertility but there is a risk for pollution. Fish ponds can be considered as a trap to capture nutrients in the IAA farms to limit nutrient losses. However, labour constraints are constraining the recycling of nutrient accumulated in the pond. Although Numon-Asia can be applied in the MD to quantify the nutrient balances of IAA farms, it is suggested that $\mathrm{N}$ leaching and gaseous losses in upland soils for fruit tress and vegetables should be further investigated for model improvement.

Acknowledgments The study was funded by the NorthSouth Inter-disciplinary Research and Education Fund (INREF Project) of Wageningen University, the Netherlands. We are grateful to Prof. Akke van der Zijp for the valuable discussions. The students Andrea Bor, Joppe de Groot, Bart Kropf, Karin Pepers, Kirsten Lamberink and Maaike van Scheppingen are acknowledged for their support with the literature review on some of the nutrient flows.

Open Access This article is distributed under the terms of the Creative Commons Attribution Noncommercial License which permits any noncommercial use, distribution, and reproduction in any medium, provided the original author(s) and source are credited.

\section{References}

Abegaz A (2005) Farm management in mixed crop-livestock systems in the Northern highlands of Ethiopia. Dissertation, Wageningen University, Wageningen

Agwe J, Morris M, Fernandes E (2007) Africa's growing soil fertility crisis: what role for fertilizer? Notes agricultural and rural development. World Bank, Washington
App A, Santiago T, Daez C, Menguito C, Ventura W, Trirol A, Po J, Watanabe I, De Datta SK, Roger P (1984) Estimation of the nitrogen balance for irrigated rice and the contribution of phototrophic nitrogen fixation. Field Crops Res 9:17-27

Bandyopadhyay KK, Sarkar MC (2005) Nitrogen use efficiency, ${ }^{15} \mathrm{~N}$ balance, and nitrogen losses in flooded rice in an Inceptisol. Commun Soil Sci Plant Anal 36:16611679

Belder P, Bouman BAM, Spiertz JHJ, Peng S, Castaneda AR (2005) Crop performance, nitrogen and water use in flooded and aerobic rice. Plant Soil 273:167-182

Can LV (1982) The muck (in Vietnamese). Agricultural Publisher, Hanoi, p 43

Carbo P, Krom MD, Homoky WB, Benning LG, Herut B (2005) Impact of atmospheric deposition on $\mathrm{N}$ and $\mathrm{P}$ geochemistry in the southeastern Levantine basin. Deep Sea Res II 52:3041-3053

Cho J-Y, Han K-W, Choi J-K, Kim Y-J, Yoon K-S (2002) N and $\mathrm{P}$ losses from a paddy field plot in central Korea. Soil Sci Plant Nutr 48:301-306

Cobo JG, Dercon G, Cadisch G (2010) Nutrient balances in African land use systems across different spatial scales: a review of approaches, challenges and progress. Agric Ecosyst Environ 136:1-15

Dalsgaard JPT, Oficial RT (1998) Modeling and analyzing the agro-ecological performance of farms with ECOPATH. ICLARM, Manila

Dang MV (2005) Soil-plant nutrient balance of tea crops in the northern mountainous region, Vietnam. Agric Ecosyst Environ 105:413-418

De Jager A, Nandwa SM, Okoth PF (1998) Monitoring nutrient flows and economic performance in African farming systems (NUTMON) I. Concepts and methodologies. Agric Ecosyst Environ 71:37-48

De Ridder N, Van Keulen H (1990) Some aspects of the role of organic matter in sustainable intensified arable farming systems in the west-African semi-arid-tropics (SAT). Fertil Res 26:299-310

DHCT (2006) Laboratory of Soil Science and Land use Management, Soil Science and Land use Management Department, College of Agriculture and Applied Biology, Cantho University, Vietnam

Dobermann A, Fairhurst T (2000) Rice: nutrient disorders and nutrient management. IRRI, Manila

Dung NNX (1996) Identification and evaluation of non-cultivated plants used for livestock feed in the Mekong Delta of Vietnam. MSc. thesis. Swedish University of Agricultural Science, Department of Animal Nutrition and Management, Uppsala, Sweden

Fan M, Liu X, Jiang R, Zhang F, Lu S, Zeng X, Christie P (2005) Crop yields, internal nutrient efficiency, and changes in soil properties in rice-wheat rotations under non-flooded mulching cultivation. Plant Soil 277:265-276

FAO (1972) Food composition table for use in east Asia. US Department of Health, Education, and Welfare and FAO, Food Policy and Nutrition Division, Rome

FAO (2001) Global estimates of gaseous emissions of $\mathrm{NH}_{3}$, $\mathrm{NO}$ and $\mathrm{N}_{2} \mathrm{O}$ from agricultural land. International Fertilizer Industry Association 
FNRI (1990) Food composition tables: recommended for use in the Philippines. Food and Nutrition Research Institute, Department of Science and Technology, Manila

Gachimbi LN, de Jager A, van Keulen H, Thuranira EG, Nandwa SM (2002) Participatory diagnosis of soil nutrient depletion in semi-arid areas of Kenya. Managing Africa's Soils No. 26, IIED, London

Gooley GJ, Gavine FM (eds) (2003) Introduction to integrated agri-aquaculture systems in Australia. Integrated agriaquaculture systems a resource handbook for Australian Industry Development. RIRDC Project No. MFR-2A. Rural Industries Research and Development Corporation, Australia

Hoa NM (2003) Soil potassium dynamics under intensive rice cropping. A case study in the Mekong Delta, Vietnam. Dissertation. Wageningen University, Wageningen, The Netherlands

Hoa NM, Janssen BH, Oenema O, Dobermann A (2006) Comparison of partial and complete soil $\mathrm{K}$ budgets under intensive rice cropping in the Mekong Delta, Vietnam. Agric Ecosyst Environ 116:121-131

Howeler RH (2001) Nutrient inputs and losses in cassavabased cropping systems-examples from Vietnam and Thailand. International workshop on nutrient balances for sustainable agricultural production and natural resource management in Southeast Asia. Bangkok, Thailand, 20-22 February 2001

Huan NH, Thiet LV, Chien HV, Heong KL (2005) Farmers' participatory evaluation of reducing pesticides, fertilizers and seed rates in rice farming in the Mekong Delta, Vietnam. Crop Protect 24:457-464

Hung NN, Singh U, Xuan VT, Buresh RJ, Padilla JL, Lap TT, Nga TT (1995) Improving nitrogen use efficiency of direct-seeded rice on alluvial soils of the Mekong River Delta. In: Denning GL, Xuan VoTong (eds) Vietnam and IRRI: a partnership in rice research. IRRI, Los Baños, pp 137-149

Khai NM, Ha PQ, Öborn I (2007) Nutrient flows in small-scale peri-urban vegetable farming systems in Southeast Asia-a case study in Hanoi. Agric Ecosyst Environ 122: 192-202

Lam NT, Patanothai A, Limpinuntana V, Vityakon P (2005) Land use sustainability of composite swiddening in the uplands of Northern Vietnam: nutrient balances of swidden fields during the cropping period and changes of soil nutrients over the swidden cycle. Int J Agric Sust 3:57-68

Liang L, Toshiyuki N, Ryusuke H (2005) Nitrogen cycling with respect to environmental load in farm systems in Southwest China. Nutr Cycl Agroecosyst 73:119-134

Lynam JK, Nandwa SM, Smaling EMA (1998) Nutrient balances as indicators of productivity and sustainability in sub-Saharan African agriculture. Agric Ecosyst Environ 71:1-4

Mason Jr WT, Rottmann RW, Dequine JF (1992) Culture of earthworms for bait or fish food. University of Florida, Institute of Food and Agricultural Sciences (UF/IFAS)

Muendo PN (2006) The role of fish ponds in the nutrient dynamics of mixed farming systems. Dissertation, Wageningen University, Wageningen, The Netherlands
Nga BT (2004) Penaeus mododon post-larvae and their interaction with Rhizophora apiculata. Disseration, Wageningen Univeristy, Wageningen, The Netherlands

Nguyen MH, Huynh TC, Tran KT (2006) Pollution of some toxic metals (Al, As, Cd, Cu, Fe, Mn, Ni, Pb, Zn) in canal water leached out from acid sulphate soils in the Mekong Delta-Vietnam in relation to available concentration of these metals in soils. 18th World Congress of Soil Science, 9-15 July 2006. Philadelphia, Pennsylvania, USA

Nhan DK (2008) The role of a fish pond in optimizing nutrient flows in integrated agriculture-aquaculture farming systems. Dissertation, Wageningen University, Wageningen, The Netherlands

Nhan DK, Milstein A, Verdegem MCJ, Verreth JAV (2006) Food inputs, water quality and nutrient accumulation in integrated pond systems: a multivariate approach. Aquaculture 261:160-173

Nhan DK, Phong LT, Verdegem MJC, Duong LT, Bosma RH, Little DC (2007) Integrated freshwater aquaculture, crop and livestock production in the Mekong delta, Vietnam: determinants and the role of the pond. Agric Syst 94: 445-458

Nielsen AH, Kristensen IS (2005) Nitrogen and phosphorus surpluses on Danish dairy and pig farms in relation to farm characteristics. Livestock Prod Sc 96:97-107

Pampolino MF, Manguiat IJ, Ramanathan S, Gines HC, Tan PS, Chi TTN, Rajendran R, Buresh RJ (2007) Environmental impact and economic benefits of site-specific nutrient management (SSNM) in irrigated rice systems. Agric Syst 93:1-24

Pansak W, Kongkeaw T, Hilger TH, Cadisch G (2005) Nitrogen losses by erosion and leaching in hillside cropping systems of Northeast Thailand as affected by soil conservation measures: a case study. Conference on international agricultural research for development. Tropentag 2005, Stuttgart-Hohenheim, 1-13 October 2005

Phong LT, Udo HMJ, van Mensvoort MEF, Tri LQ, Bosma RH, Nhan DK, van der Zijpp AJ (2008) Integrated agriculture-aquaculture systems in the Mekong Delta, Vietnam: an analysis of recent trends. Asian J Agric Dev 4:51-66

Powel JM, Unger PW (1997) Alternatives to crop residues as soil amendments. In: Renard C (Ed) Crop residues in sustainable mixed crop/livestock farming systems. ICRISAT, India and ILRI, Kenya, pp 215-239

Roger PA, Ladha JK (1992) Biological N fixation in wetland rice fields: estimation and contribution to nitrogen balance. Plant Soil 141:41-55

Roy RN, Misra RV, Lesschen JP, Smaling EMA (2003) Assessment of nutrient balance. Approaches and methodologies. FAO Fertilizer and Plant Nutrition Bulletin 14, FAO, Rome

Shan Y-H, Yang L-Z, Yan T-M, Wang J-G (2005) Downward movement of phosphorus in paddy soil installed in largescale monolith lysimeters. Agric Ecosyst Environ 111:270-278

Shiratani E, Yoshimaga SRK (2005) Model analysis for nitrogen effluent from upland field constructed with under-drain. Water Sci Technol 51:91-98 
Smaling EMA, Fresco LO (1993) A decision-support model for monitoring nutrient balances under agricultural land use (NUTMON). Geoderma 60:235-456

Smaling EMA, Stoorvogel JJ, Windmeijer PN (1993) Calculating soil nutrient balances in Africa at different scales II. District scale. Fertil Res 35:237-250

Stoorvogel JJ (2007) From nutrient balances towards soil organic matter dynamics. In: Van de Zijp M et al (eds) Fishponds in farming systems. Wageningen Academic Press, Wageningen, pp 107-124

Stoorvogel JJ, Smaling EMA (1990) Assessment of soil nutrient depletion in Sub-Saharan Africa. Winand Staring Centre, Report 28. Wageningen, The Netherlands

Surendran U, Murugappan V (2006) A micro- and meso-level modeling study for assessing sustainability in semi-arid tropical agroecosystem using NUTMON-toolbox. J Sust Agric 29:151-179

Surendran U, Murugappan V, Bhaskaran A, Jagadeeswaran R (2005) Nutrient budgeting using NUTMON_-Toolbox in an irrigated farm of semi arid tropical region in India- a micro and meso level modeling study. World J Agric Sci 1:89-97

Van den Bosch H, Gitari JN, Ogaroc VN, Maobe S, Vlaming J (1998) Monitoring nutrient flows and economic performance in African farming systems (NUTMON). III. Monitoring nutrient flows and balances in three districts in Kenya. Agric Ecosyst Environ 71:63-80
Van der Pol F (1992) Soil mining. Bulletin 325, Royal Tropic Institute (KIT), Amsterdam

Vlaming J, Van den Bosch H, Van Wijk MS, De Jager A, Bannink A, Van Keulen H (2001) Monitoring nutrient flows and economic performance in tropical forming systems (NUTMON). Alterra and LEI, Wageningen

White I (2002) Water management in the Mekong Delta: changes, conflicts and opportunities. Centre for Resource and Environmental Studies. IHP-VI, Technical Documents in Hydrology, No. 61. UNESCO, Paris

Wijnhoud JD (2007) Nutrient budgets, soil fertility management and livelihood analyses in Northeast Thailand: a basis for integrated rural development strategies in developing countries. Dissertation, Wageningen University, Wageningen, The Netherlands

Xing GX, Zhu ZL (2000) An assessment of N loss from agricultural fields to the environment in China. Nutr Cycl Agroecosyst 57:67-73

Yem VH, Tuan PQ, Dao NT (2001) Cultivation, soil, fertilizer, variety (in Vietnamese). Vol. 1. Education Publisher, Thanh Hoa

Yoon KS, Choi JK, Son JG, Cho JY (2006) Concentration profile of nitrogen and phosphorus in leachate of a Paddy Plot during the rice cultivation period in Southern Korea. Commun Soil Sci Plant Anal 37:1957-1972 